\title{
Kematian Neonatal dan Bayi Lahir Mati serta Hubungannya dengan Kepercayaan dan Perilaku Masyarakat
}

\author{
Rizanda Machmud, ${ }^{1}$ Yunarti ${ }^{2}$ \\ ${ }^{1}$ Ilmu Kesehatan Masyarakat dan Ilmu Kedokteran Komunitas, Fakultas Kedokteran \\ ${ }^{2}$ Antropologi Kesehatan, Fakultas Ilmu Sosial dan Politik \\ Universitas Andalas, Padang
}

\begin{abstract}
Abstrak
Kabupaten Cirebon memiliki angka kematian ibu dan bayi yang tinggi. Berbagai upaya sudah dilakukan untuk menurunkan angka tersebut, namun belum berhasil. Penelitian ini bertujuan untuk menggali informasi yang lebih mendalam tentang keterkaitan kematian bayi lahir mati dan neonatal dengan latar belakang perilaku serta kepercayaan masyarakat tentang kehamilan, persalinan, dan perawatan bayi baru lahir di desa pesisir dan pedalaman. Pendekatan penelitian menggunakan paradigma gabungan antara kualitatif dan kuantitatif (mixed paradigm) dengan menggali informasi secara mendalam mengenai faktor predisposing, faktor enabling, dan faktor reinforcing kepercayaan serta perilaku masyarakat. Penelitian dilakukan di desa Weru Lor (pedalaman) dan Suranenggala (pesisir) di kabupaten Cirebon, Jawa Barat pada tahun 2006. Hasil penelitian menunjukkan adanya stigma-stigma yang melatarbelakangi perilaku tidak rasional dalam hubungannya dengan kematian bayi lahir mati dan neonatal. Tidak terdapat perbedaan kepercayaan antara desa pedalaman dan desa pesisir. Kesimpulan penelitian ini adalah perlunya kompetensi petugas kesehatan dalam penyebarluasan informasi rasional sehingga mampu menghilangkan stigma-stigma yang tumbuh dalam masyarakat. [MKB. 2010;42(1):22-6].
\end{abstract}

Kata kunci: Kematian neonatal, bayi lahir mati, kepercayaan, dan perilaku

\section{Relationship Between Neonatal Mortality and Still Birth with Believe and Behavior of Health Society}

\begin{abstract}
Cirebon's district is one of highest infant mortality and maternal mortality rate. So many efforts have been done to reduce this rate but, it's no effect yet. The etiology of these problems isn't known. The aim of research was to discover deeper information about relationship between neonatal mortality and social behavior background and believe of health society in pregnancy, delivery and antenatal care in mainland and coastal district. A qualitative and quantitative methods were used to exploring deeper information about predisposing, enabling, and reinforcing factors in health believe and behavior in society. Location of the study were in mainland (Weru Lor) and costal village (Suranenggala) in Cirebon-West Java in 2006. This research answered the reseach question, why neonatal death are happened and why health behavior in society seems irrational. There were stigmas in society that affect infant mortality rate. The result of research showed there were existence of stigmas which was irrational background in its relation with infant and neonatal mortality. There were no difference of local culture, knowledge, and believe among mainland and coastal countryside. Conclusion of this research is the importance of provider of health competence in dissemination of rational information so that can eliminate stigmas which grow in society.
\end{abstract}

[MKB. 2010;42(1):22-6].

Key words: Neonatal mortality, still birth, believe, behavior

Korespondensi: Dr. dr. Rizanda Machmud, M.Kes., Bagian Ilmu Kesehatan Masyarakat dan Ilmu Kedokteran Komunitas, Fakultas Kedokteran Universitas Andalas, Jln. Perintis Kemerdekaan Padang, Hp. 08126623467,

Email:rizanda_machmud@yahoo.com/rizandamachmud@fk.unand.ac.id 


\section{Pendahuluan}

Deklarasi Alma Ata 1978 mencanangkan sebuah upaya global untuk mencapai target "kesehatan bagi semua pada tahun 2000", terutama untuk mengatasi masalah kesehatan masyarakat miskin di negara berkembang dengan prinsip kesamaan dan keadilan sosial. Meskipun demikian, sampai saat ini masih terdapat kerentanan baik secara struktural, sosial, maupun ekonomi sehingga tanggungan beban sakit masih tinggi (the burden of illness). ${ }^{1,2}$

Sumber Biro Pusat Statistik (BPS) 2004 menyebutkan bahwa angka kematian bayi (AKB) di Indonesia masih tertinggi di wilayah negara ASEAN. Salah satu faktor penting tingginya AKB di Indonesia adalah masih banyaknya perilaku masyarakat pedesaan yang tidak rasional dalam hal kehamilan, persalinan, dan perawatan bayi baru lahir. ${ }^{2,3}$

Oleh karena Kabupaten Cirebon, Jawa Barat masih memiliki AKB yang tinggi dan terdapatnya perbedaan budaya antara pedesaan pesisir dengan pedalaman, maka penelitian ini bertujuan untuk menggali informasi secara menyeluruh dalam mengungkapkan kepercayaan serta perilaku masyarakat tentang kehamilan, persalinan, dan perawatan bayi baru lahir dalam kaitannya dengan mati dan kematian neonatal.

\section{Metode}

Penelitian kualitatif ini dilakukan dengan dua tingkat yaitu: tingkat keluarga dan desa. Penelitian dilakukan di pantai Weru Lor dan pegunungan Suranenggala, kabupaten Cirebon. Pemilihan lokasi ini didasarkan pada data angka kematian neonatus yang tinggi di antara kabupaten dan kotamadya di Provinsi Jawa Barat. Wawancara mendalam dilakukan terhadap 18 orang dari 8 kelompok diskusi.

Informasi di tingkat keluarga dilakukan wawancara terhadap ibu-ibu dan suami terkait yang mengalami kematian bayi, petugas kesehatan/bidan desa atau dukun paraji, serta ibu dan bapak yang memiliki anak balita yang tidak pernah mengalami kematian neonatal. Pada tingkat desa, masing-masing di Weru Lor dan desa Suranenggala, diwawancarai kepala urusan Kesra, bidan desa, dan tokoh agama/lebe.

Analisis data menggunakan matriks hasil reduksi wawancara yang dikelompokkan dalam karakteristik serta pola yang sama, sedangkan untuk pemeriksaan keabsahan data digunakan triangulasi sumber, metode, dan data.

\section{Hasil}

Distribusi umur penduduk kabupaten Cirebon didapatkan umur muda (0-14 tahun) 32,56\%, umur produktif (15-64 tahun) 63,55\%, dan penduduk tua ( $\geq 65$ tahun) $3,88 \%$. Angka kelahiran kasar Crude Birth Rate (CBR) sebesar 19,54 per 1.000 penduduk, lebih rendah dari angka nasional, tetapi angka kematian kasar crude death rate (CDR) sebesar 12,59 per 1.000 penduduk lebih tinggi dari angka nasional. Angka kematian bayi sebesar 11,83 per 1.000 kelahiran hidup. Tingkat kelahiran berpengaruh besar terhadap struktur penduduk muda.

Tingkat pendidikan sebagian besar penduduk, baik laki-laki maupun perempuan adalah tamat Sekolah Dasar/Madrasah Ibtidaiyah, mayoritas beragama Islam, dan mata pencaharian terbesar adalah buruh, dengan rata-rata pengeluaran per bulan Rp. 105.418,-. Sebagian besar perempuan adalah buruh batik yang bekerja di rumah.

Sarana kesehatan terdiri atas 6 rumah sakit, 44 puskesmas, 3 rumah sakit bersalin, seluruhnya terdapat 277 sarana kesehatan. Rasio tenaga medis terhadap 100.000 penduduk adalah 1:8,82, sedangkan rasio tenaga kesehatan masyarakat terhadap 100.000 penduduk adalah 1: 0,95. Hasil penelitian terhadap 4 kematian neonatal adalah sebagai berikut:

Kasus 1, ibu dengan kematian neonatal pada usia 17 hari, karena ikterus, di desa Weru Lor. Pengetahuan, sikap, serta penilaian ibu terhadap kesehatan bayi masih kurang. Masyarakat masih menganggap bahwa bayi kuning itu adalah hal biasa, sehingga terjadi keterlambatan untuk memeriksakan bayi kuning. Pengetahuan petugas kesehatan tentang ikterus masih kurang. Ketika terjadi tanda bahaya klinis seperti bayi lemas, bayi tidak mau menetek yang menunjukkan tanda dehidrasi dan sepsis, maka seharusnya segera diambil tindakan. Penyediaan sarana prasarana kasus bayi ikterus memerlukan pemantauan pemeriksaan darah yang ketat, sulit jika hanya berobat jalan, tampaknya sarana dan prasarana untuk pemantauan ini tidak ada. Di samping itu, tidak didapatkan upaya mendorong perawatan di 
Tabel Matriks Faktor-faktor Permasalahan Menurut Faktor Predisposing, Faktor Enabling, dan Faktor Reinforcing

\begin{tabular}{cccc}
\hline Kasus & $\begin{array}{c}\text { Faktor predisposing } \\
\text { Pengetahuan, sikap dan } \\
\text { nilai, serta persepsi }\end{array}$ & $\begin{array}{c}\text { Faktor } \text { enabling } \\
\text { Ketersediaan fasilitas } \\
\text { kesehatan dan penanganan } \\
\text { kematian bayi }\end{array}$ & $\begin{array}{c}\text { Faktor reinforcing } \\
\text { Kemampuan teman, orangtua, } \\
\text { kerabat mengidentifikasikan, } \\
\text { menjaga kehamilan, persalinan, dan } \\
\text { perawatan bayi baru lahir }\end{array}$ \\
\hline 1 & Negatif & Negatif & Negatif \\
2 & Negatif & Positif & Negatif \\
3 & Negatif & Negatif & Negatif \\
4 & Negatif & Negatif & Negatif \\
\hline
\end{tabular}

rumah sakit dari bidan dan petugas kesehatan.

Kasus 2, ibu dengan kematian neonatal saat melahirkan dengan usia kandungan 5 bulan di desa Weru Lor. Pengetahuan, sikap, dan penilaian ibu terhadap kesehatan bayinya masih kurang. Kesadaran akan pentingnya menjaga kesehatan bayi dalam kandungan dan menghindarkan risiko kematian bayi yang dikandungnya masih kurang. Sarana dan prasarana yang ada sudah mencukupi untuk penanganan bayi imatur yaitu di rumah sakit. Peran faktor lingkungan yang mendorong ibu untuk menjaga kehamilannya, seperti suami atau keluarga juga masih kurang.

Kasus 3 adalah ibu dengan kematian neonatal kembar, berat badan lahir rendah (BBLR): satu bayi dilahirkan setelah 2 jam dan satunya lagi lahir setelah 3 hari, partus lama, di desa Weru Lor. Ibu melakukan antenatal care secara berkala. Ibu tidak memahami perbedaan risiko persalinan kembar dengan persalinan normal, sehingga tetap memilih dukun karena merasa aman. Setelah dilakukan penelusuran ternyata dukun bayi baru menyadari adanya kelahiran kembar setelah bayi pertama lahir. Peran keluarga dalam mendorong ibu untuk memeriksakan kehamilannya ke sarana kesehatan amat kurang.

Kasus 4, ibu dengan kematian neonatal akibat persalinan yang lama (partus lama), bayi lahir mati, di desa Suranenggala. Pada kasus ini, terlihat bahwa masyarakat masih lebih mempercayakan persalinan pada dukun terlebih dahulu, bila ada kendala baru dipanggil bidan. Faktor predisposing berupa pengetahuan, sikap, dan nilai yang dianut masyarakat masih ke arah negatif. Persalinan yang disukai adalah persalinan yang berlangsung di rumah. Hal ini untuk menimbulkan kenyamanan pada ibu sementara sarana dan prasarana untuk membantu persalinan terbatas. Pada kasus ini, proses persalinan sudah berlangsung selama 10 jam, yang berarti 2 jam lebih lama dari persalinan normal. Tidak ada dorongan dan inisiatif keluarga untuk meminta anggota keluarga yang bersalin agar dirujuk.

Matriks arah permasalahan menurut faktor predisposing, enabling, dan reinforcing terhadap kematian bayi lahir mati dan neonatal yang berhubungan dengan perilaku masyarakat, dapat dilihat pada tabel.

Hubungan antara kematian bayi lahir mati dan neonatal dengan kepercayaan serta perilaku masyarakat antara desa pesisir dan pedalaman di kabupaten Cirebon menunjukkan tidak terdapat perbedaan antara desa pedalaman Weru Lor dan pesisir Suranenggala. Masih terdapat sebagian besar kepercayaan dan tradisi yang kuat akan makna kematian, yang disebabkan oleh faktor di luar kesehatan. Makna peran kesehatan dalam mencegah kematian bayi masih belum terbentuk di masyarakat.

Kasus tersebut di atas menunjukkan bahwa masyarakat masih mempercayakan persalinan normal kepada dukun, bila bermasalah baru pada tenaga kesehatan. Di samping itu, kemampuan bidan untuk kasus gawat darurat masih kurang. Kebutuhan sarana prasarana penunjang untuk kasus gawat darurat maternal masih kurang.

Penilaian yang dilakukan meliputi lingkungan sekitar serta menghimbau ibu-ibu dalam usaha pencegahan kematian bayi. Faktor reinforcing ternyata bersifat negatif. Orangtua justru masih mendorong untuk mengerjakan pantangan yang ada. Dalam hal ini pertugas kesehatan tidak dapat berbuat lebih banyak, karena pantangan dan kepercayaan tersebut masih melekat kuat.

Selain itu terdapat stigma di masyarakat yang sangat merugikan perkembangan pada kehamilan. Berikut ini pantangan yang ada di masyarakat yang masih ditaati ibu-ibu hamil untuk menjaga 
kehamilannya, seperti pantangan makanan.

Beberapa pantangan perilaku selama ibu hamil di antaranya: tidak keluar malam, suami tidak boleh kalungan handuk atau sarung untuk menghindari bayi terlilit tali pusar, tidak boleh banyak tidur karena bayi akan mengalami bercak putih di pipi, dan tidak boleh membuang air cucian ke kaki karena dapat membuat kaki bengkak. Pantangan makanan pada kehamilan antara lain: tidak boleh makan makanan pedas, tidak boleh makan udang karena akan membuat persalinan maju mundur, tidak boleh makan blekutak (sejenis cumi besar) karena bayi akan terlihat seperti cumi, tidak boleh makan kepiting karena juga akan melihat persalinan maju mundur, tidak boleh makan kerupuk karena akan menyebabkan anak seperti angin dan tidak bertenaga, tidak boleh makan terong karena akan membuat anak kecil, tidak boleh makan es agar anak tidak besar dan tidak boleh makan kerupuk melarat.

Apabila dilihat dari pantangan makanan yang dilakukan oleh penduduk desa Weru Lor dan Suranenggala, ternyata makanan yang memiliki protein tinggi yang dijadikan pantangan makanan. Hampir semua ibu hamil mematuhi pantangan dan kepercayaan yang ada, karena umumnya takut jika melanggar pantangan akan menyebabkan risiko pada kehamilan dan persalinan.

\section{Pembahasan}

Hasil penelitian menunjukkan bahwa faktor yang mendasari suatu kepercayaan dan perilaku masyarakat dalam menjaga kehamilan sangat erat. Kepercayaan dan perilaku masyarakat tentang kehamilan, persalinan, dan perawatan bayi baru lahir masih dipengaruhi oleh dasar pemikiran, kepercayaan terhadap apa yang dikatakan oleh orangtua, kebiasaan serta adat istiadat yang diturunkan oleh generasi sebelumnya, bukan disebabkan karena kurangnya pengetahuan saja, tetapi mempunyai akar masalah yang lebih dalam. ${ }^{4-5} \mathrm{Hal}$ ini sesuai dengan penelitian Swasono dan Meutia, ${ }^{6}$ tentang kehamilan, kelahiran, serta perawatan ibu dan bayi dalam konteks budaya, belum ada perubahan dari tahun ke tahun. Begitu juga laporan dari kantor berita Antara, tahun 2007 yang menyebutkan bahwa penurunan angka kematian ibu belum sesuai target MDGs.

Hasil penelitian di atas dapat disimpulkan bahwa faktor predisposing, tentang pengetahuan, sikap dan nilai, serta persepsi masyarakat masih bersifat negatif. Ketika sampai pada mengambil keputusan, bukan ditentukan oleh ibu hamil itu sendiri, tetapi didominasi oleh suami, orangtua bahkan keluarga besar. ${ }^{5,6}$

Faktor enabling ternyata menunjukkan arah negatif, yaitu masih minimnya kualitas dan sarana serta prasarana kesehatan dalam pemeriksaan kehamilan. Pentingnya peningkatan mutu layanan dan pelatihan sebagai penyegaran, terutama untuk kasus gawat darurat kebidanan. ${ }^{7,8}$

Faktor reinforcing terdiri dari kemampuan teman, orangtua, kerabat mengenai identifikasi, menjaga kehamilan, persalinan serta perawatan bayi baru lahir, hasilnya juga negatif. Besarnya peran lingkungan dalam pengambilan keputusan perlu menjadi perhatian bagi petugas kesehatan dalam kegiatan penyuluhan. ${ }^{8}$ Pengambilan keputusan terhadap ibu hamil di masyarakat kabupaten Cirebon belum pada diri ibu itu sendiri, tetapi masih didominasi oleh suami atau orangtua bahkan keluarga besar. Dalam hal ini petugas kesehatan tidak dapat berbuat lebih banyak, karena pantangan dan kepercayaan tersebut masih melekat kuat, sehingga penting bagi petugas kesehatan mengenali siapa pengambil keputusan dalam keluarga. Promosi kesehatan juga harus memperhatikan target dari sasaran penyuluhan kesehatan, tidak hanya ibu tetapi melibatkan keluarga. Di beberapa negara kondisi ini ternyata masih sama, seperti di negara Kanada melaporkan bahwa pengalaman tenaga kesehatan terhadap keluarga yang dilayani sangat penting karena turut mempengaruhi dalam keselamatan persalinan, ${ }^{4}$ begitu juga di Afganistan. 9.10

Hasil penelusuran kualitatif menunjukkan bahwa masih terdapat pekerjaan rumah yang cukup berat yaitu adanya kepercayaan serta perilaku masyarakat yang berkaitan erat dengan permasalahan dan tantangan tingginya angka kematian bayi di Indonesia. Pola di kabupaten Cirebon hampir sama dengan penelitian yang dilakukan Ronoatmodjo 5 di kecamatan Keruak, Nusa Tenggara Barat tentang faktor risiko kematian neonatal akibat minimnya pengetahuan masyarakat. Kendala-kendala ini juga dialami oleh negara lainnya di dunia terutama di daerah pedesaan. ${ }^{10,11}$

Penelitian ini menunjukkan adanya perilaku masyarakat yang terkesan tidak rasional, karena adanya stigma yang melatarbelakangi perilaku tersebut. Upaya untuk menurunkan kematian bayi 
adalah dengan menghilangkan stigma tersebut.

Diperlukan kompetensi petugas kesehatan dengan mengupayakan langkah-langkah yang dilakukan dalam penyebarluasan informasi. Materi penyuluhan harus mampu menjawab dan menghilangkan stigma yang tumbuh di dalam masyarakat yang bersifat local guine tentang kaitan kematian bayi lahir mati dan kematian neonatal dengan latar belakang pemikiran, motivasi, tata nilai, adat istiadat dan kepercayaan masyarakat yang mendasari pengetahuan, sikap dan tindakan masyarakat tentang kehamilan, persalinan, serta perawatan bayi baru lahir di desa pesisir dan desa pedalaman di kabupaten Cirebon, Jawa Barat.

Di samping itu dalam rangka penyuluhan, sasaran target sebaiknya tidak hanya ibu-ibu tetapi harus melibatkan keluarga seperti suami dan orangtua. Hal ini sangat penting karena pengambil keputusan dalam keluarga bukanlah ibu-ibu sasaran, tetapi didominasi oleh orangtua ibu dan suami, sehingga akan lebih efektif jika dilakukan pada tingkat keluarga.

Masih diperlukan peningkatan kualitas sarana dan prasarana yang sudah ada serta pelatihan penyegaran untuk petugas kesehatan, agar lebih siap dalam mengantisipasi masalah atau kasus gawat darurat kebidanan di lapangan.

\section{Daftar Pustaka}

1. UNDP Publication, MDGS Goal 5. Laporan perkembangan pencapaian tujuan pembangunan milenium Indonesia: Meningkatkan kesehatan ibu dengan menurunkan angka kematian ibu sebesar tiga perempatnya antara 1990 dan 2015. Indonesia; 2003.

2. Unicef. Analisa situasi anak-anak di indonesia. Jakarta: Unicef; 2000

3. Departemen Kesehatan RI. Rencana strategis nasional, making pregnancy safer di Indonesia 2001-2010. Jakarta: Depkes; 2001.

4. Antara News. WHO: penurunan angka kematian ibu belum sesuai target MDGs. 2007.

5. Ronoatmodjo. Faktor risiko kematian neonatal di kecamatan Keruak, Nusa Tenggara Barat 19921993 (disertasi). Depok: Universitas Indonesia; 1996.

6. Swasono F, Meutia M. Kehamilan, kelahiran, perawatan ibu dan bayi dalam konteks budaya. Jakarta: Universitas Indonesia Press; 1998.

7. Grzybowski S, Kornelsen J, Cooper E. Rural maternity care services under stress: the experiences of providers. Canadian J Rural Med. 2007:89.

8. Dooley J, Len K, Peirre-Hansen N, St Antone I, O'Driscoll T, Guilfoyle J. Rural and remote obstetric care close to home: program description, evaluation and discussion of Sioux Lookout Meno Ya Win Health Centre Obstetris. Canad J Rural Med. 2009 March:22.

9. Mayhew M. Shame and simplicity in afghanistan. Canad Med Associ J. 2009; 180 (8):896-10.

10. Van de Poel E, O'Donnell O, van Doorslaer E. What explains the rural-urban gap in infant mortality: household or community characteristics? Demography. 2009;46(4): 827-35.

11. Bartlett LA, Mawji S, Whitehead SC. Where giving birth is a forecast of death: maternal mortality in four distric. Lancet. 2005 Mar:864-8. 